Winter 2008

\title{
Rethinking NGOs: The Economy of Survival and Global Governance
}

Marc Abélès

Ecole des Hautes Etudes en Sciences Sociales, Paris

Follow this and additional works at: https://www.repository.law.indiana.edu/ijgls

Part of the Civil Law Commons, and the International Law Commons

\section{Recommended Citation}

Abélès, Marc (2008) "Rethinking NGOs: The Economy of Survival and Global Governance," Indiana Journal of Global Legal Studies: Vol. 15 : Iss. 1 , Article 10.

Available at: https://www.repository.law.indiana.edu/ijgls/vol15/iss1/10

This Symposium is brought to you for free and open access by the Law School Journals at Digital Repository @ Maurer Law. It has been accepted for inclusion in Indiana Journal of Global Legal Studies by an authorized editor of Digital Repository @ Maurer Law. For more information, please contact rvaughan@indiana.edu.

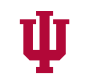

JEROME HALL LAW LIBRARY

INDIANA UNIVERSITY

Maurer School of Law
Blooming ton 


\title{
Rethinking NGOs: The Economy of Survival and Global Governance
}

\author{
MarC AbÉLÈs*
}

Abstract

This article explores the concept of "global politics," an evolving set of systems that undermine our traditional view of government. These underlying systems, including Non-Governmental Organizations (NGOs), exert great influence on the power and actions of nation-states. Thus, while current global politics are largely dependent on the actions and strategies of nation-states, nation-states are not the only actors at work. The article argues for a view of global politics that takes these other systems, particularly NGOs, into account.

\section{INTRODUCTION}

Since the end of the 1980s, I have done anthropological fieldwork in transnational institutions and organizations including the EU Commission and Parliament, and more recently in a Non-Governmental Organization (NGO) called Oxfam. This paper presents NGOs as part of what I call "global politics."

When we look back over the last ten years, the remarkable conjunction of two phenomena is striking. On one hand, transnational organizations have partly taken charge of a certain number of the key elements of governance in areas as diverse as the economy, the environment, and the rights of man. On the other hand, a battlefront has developed that targets these new powers.

This means there is a dual displacement in both governmentality and resistance. In reality, what characterizes the present is the emergence of a new political stage set with its own specific figures and challenges whose true place can be

* Professor, Ecole des Hautes Etudes en Sciences Sociales, Paris. This is a lightly edited version of a presentation delivered at the Indiana Journal of Global Legal Studies Symposium on Democracy and the Transnational Private Sector, Indiana University School of Law-Bloomington, April 12, 2007. 
gauged when confrontations occur, like those that marked the WTO meetings and the G7 summits. Davos, Switzerland and Porto Alegre, Brazil have become the symbols of the political displacement.

The increasing power of the transnational on a planetary scale is only the tip of the iceberg. Deep down, what is at issue is the very meaning we give today to the business of politics, and our perception of the political dimension that is radically changing. This article argues that political displacement is the consequence of a global redefinition of the meaning and aims of political action. This redefinition not only has a cognitive dimension, but also shows up in ways of acting, in organizational and institutional constructions, in the position of issues that will be a focus for public debate, and in the construction of the type of site where this debate will happen. This theory is heavy with consequences; it effectively implies that the emergence of a new, transnational stage is the effect rather than the cause of a profound transformation of our relationship to politics. This means that, in research, the institutional process must give way to an investigation of our perception of politics. It is here that the displacement, whose most visible effects we have spotted, is really happening.

The thesis of my argument is that the political displacement, i.e., the weakening of the state, reflects the rise in power of political representation that puts the preoccupations of life and survival at the heart of political action, while the issue of the city and the relationship of the individual to sovereignty are relegated to the background. The displacement of issues finds another expression in a simple question that we all ask: "What will our world consist of tomorrow?" It is this fundamental anxiety that not only alters our relationship to politics but also determines the space that can be allocated to this activity and the new sites in which it is best exercised. My last book ${ }^{1}$ argued that the issue of survival has currently become the focal issue in our democracy, where living together harmoniously (convivance) has been an issue for several centuries. In this context we can better understand the specific role of NGOs as protagonists in transnational public space. The goal of this paper is to point out the specific link between the rise of NGOs as part of the reconfiguration of the transnational sphere of powers and the growing importance of new forms of governmentality focused on the economy of survival.

The entrance of NGOs as protagonists in transnational public space caused many interrogations and criticisms concerning the legitimacy of this type of organization, including skepticism about their ambition to open a new political space. The main question addressed to NGOs refers to their legitimacy. Are they, in the final analysis, the instrument of a self-proclaimed elite, a kind of "militant jet set"? When

1. Marc Abélès, Politique de la Survie (2006). 
we raise the problem of NGOs' representativeness, we are forced to acknowledge that their decisions are made by individuals who have not been elected. During international negotiations, they deal with government representatives who wield power as a result of democratic procedures. The NGO leaders themselves can only find their legitimacy in the universality and cogency of the cause that they defend. They are self-proclaimed spokespeople of "civil society," a term whose usage is often unclear, both in regards to what it covers and whether its use intentionally flattens a universe whose diversity is then reduced to a standardizing expression. A discourse unified behind consensual slogans (e.g., the fight against poverty, the reduction of the greenhouse effect, and fair trade) diffuses a non-critical definition of "the general interest" and "universal goods." NGO leaders also implicitly refer to the existence of a community that would be the fruit of globalization.

NGOs answer this criticism concerning their legitimacy by presenting several arguments. The first relates to their proximity to the ground. They are directly confronted with humanitarian crises and poverty. It is their work in the field that makes them the essential spokespeople of groups which, without them, would be abandoned to destitution or precariousness. Another argument relates to their detachment compared to the often political motivations controlling governmental action. They are not pledged to any established order. NGOs also argue that they have a true capacity of expertise. Their action is haloed by technical legitimacy. Such an argument implies a reinforcement of the power of experts by the counter-evaluations that they bring. We are witnessing a "privatization" of the international regulation among NGOs. Regarding the environment or finance, on questions of debt or of ethical trade, the standards are discussed between consultants and actors of the commercial private sector without political arbitration.

Paradoxically, in these debates, we undoubtedly lose sight of the essential. The influence of NGOs and the audience that they gather among citizens are due to the fact that through them we hear the echo of an entire rejected humanity, those who seem abandoned on behalf of modernity. According to the striking expression of the sociologist Zygmunt Bauman, one of the most profound effects of globalization and the new conflicts that it produces, such as "peaceful" research of profit on a global scale, is to reduce a mass of humans to the state of pure waste, to wasted lives. ${ }^{2}$ These human beings lost their quality as citizens to be no more than "naked lives,"3 populations shunted between clandestineness and refugee

2. Zygmunt Bauman, Wasted Lives: Modernity and Its Outcasts 6-7 (2004).

3. Giorgio Agamben, Means Without End: Notes on Politics 20-21 (Vincenzo Binetti \& Cesare Casarino trans., Univ. of Minn. Press 2000). 
camps. But all these people are truly there and they do not cease knocking on the doors of the universe of the rich to be generally rejected with a violence of which we are aware. And the place that NGOs occupy in public space depends foremost on the actions that they carry out to ensure their survival.

One can certainly dispute criticisms of NGOs that highlight their lack of democratic legitimacy by stressing that the authorities who claim to be the most democratic-parliaments and governments - are shown to be quite slow in reacting to human rights violations or to the serious attacks on the planet's ecological integrity. Without NGOs and their transnational activism, laxity could have prevailed. Moreover, we would have undoubtedly never seen far-reaching initiatives like the Conference of Rio, which put the question of sustainable development on the agenda. The end of the twentieth century will be remembered for the progressive rise to power of a broad movement that came to counterbalance the most harmful effects of globalization.

Similarly, it is clear that we will not reconsider the participation of NGOs in important international negotiations. What has been introduced is another manner of considering the political, not only as the everyday management of the polis, but as the need for treating world affairs in a way where we take seriously the survival of the planet and the need for the poorest to be heard in the public domain. This public space has been widened beyond the limits that institutions once set for it, in part because those institutions have been exceeded on an economic and ecological level by the reach of globalization. Even if we would be wrong to undervalue "the resistance of the states" and the way that intergovernmental relations continue to direct global destinies, there is no doubt that NGOs, thanks to their privileged partnership with large transnational organizations, introduced a new situation. We are seeing the advent of forms of action privileging lobbyism and media pressure at the cost of traditional practices of diplomacy centered on the respect of certain balances, including the old argument of power relations in the background. However, if this kind of situation functions within a framework that puts a premium on the reference to the nation, when NGOs claim the causes they defend by ignoring arguments about national borders, then there is a risk of disorder in the well-oiled play of state powers and international organizations. From one day to the next, complicity can be endangered by the revelation of the unacceptable. In this way, even with a subaltern appearance in terms of their political role, the impact of these transnational actors has become strong enough that

4. Samy Cohen, La Résistance des États: Les Démocraties Face aux Défis de la MondiALISATION (2003). 
states must anticipate their effects when developing state strategies. We would be wrong, however, to lock ourselves into a debate of an altogether academic nature, while it is now a more profound question of opening our representations and our apprehension of the political to interrogations that previously escaped them.

From this point of view, it seems that the grand question projected by NGOs in the center of public space is that of the economy of survival, so that they force nolens volens the traditional sphere of international relations to take on a new form of reflexivity centered on this economy. To give one example of this process, I will take the case of the campaigns carried out by Oxfam. The Oxford Committee for Famine Relief was created in 1942 by two academics and a British businessman to provide food to Greece, which was then occupied by the Nazis and suffering from the allied blockade. They put together 12,000 pounds that they gave to the Greek Red Cross. ${ }^{5}$ After the war, the organization intervened in India to cure a famine in Bihar. Thereafter, it was present in all the engagements against hunger and misery in the countries of the South, from battered Cambodia in 1979 to devastated Ethiopia to the refugee camps of Rwanda in 1994.

More recently, from Kosovo to Mozambique, from Sudan to Bangladesh, there is no humanitarian emergency that Oxfam misses. It also intervenes in the West in impoverished zones. Oxfam has become one of the most prominent NGOs in the humanitarian field. On its website, it summarizes its principles of action in the following way: "We work with the poor people," "we influence powerful people," "we join hands with all people." These are ways of saying that it combines three essential activities: development and humanitarian aid; campaigns and lobbying to influence international policies and practices; and finally, the mobilization of the general public concerning these issues.

With an annual budget of $\$ 1.3$ billion, Oxfam has the means to achieve its multiple ambitions. Today, it is a confederation of thirteen organizations, operating in several countries of Europe, Canada, the United States, Australia, Hong Kong, and Africa, as well as a network of active associations in more than 100 countries. Oxfam counts 200,000 members and employs 3,500 permanent workers. In addition to its various organizations, it opened offices in London, Brussels, Geneva, and New York, where the British Parliament, the European Commis-

5. Maggie Black, A Cause for Our Time: Oxfam the First 5o Years 13, 16 (1992).

6. Oxfam International, About $U s$, http://www.oxfam.org/en/about/index.htm (last visited Jan. 16, 2008). 
sion, the World Trade Organization, and the United Nations sit, respectively. ${ }^{\top}$ I went to Broad Street, in the center of Oxford, where the head office of Oxfam Great Britain and Oxfam International occupies two entire buildings. The personnel who devote themselves to campaign organization and media relationships are gathered in one building on several floors. On the other side of the street, an "Oxfam shop" sells inexpensive products, which are in fact gifts from British people. The collected money makes it possible to promote actions on the ground. If Max Havelaar was a pioneer by opening the first fair trade store in the Netherlands at the end of the 1960s, Oxfam is now at the head of the movement, with 850 shops open in Great Britain.

Oxfam's work in the development and humanitarian aid sectors falls under a vast strategy that begins with the principle that "poverty is a state of powerlessness in which people are unable to exercise their basic human rights." these rights: the right to a sustainable means of subsistence, the right to basic social services, the right to life and safety, the right to be heard, and the right to an identity. Oxfam implements multi-annual strategic plans founded on the defense of economic and social rights. Beginning in the 1960s, Oxfam launched what was going to become the great adventure of free trade by creating bonds with producers in developing countries, finding outlets for their products, and relentlessly recovering clothing and other second hand goods to resell at low prices.

The 2001-2004 strategic plan, "Towards Global Equity," targeted improving southern countries' access to the market." "For every 100 euros generated by the world trade, 3 go to developing countries." ${ }^{10}$ On the basis of this observation, Oxfam decided to conduct a campaign for fairer globalization. Towards this objective, it invested in the preparation of the new cycle of WTO negotiations that were to open in September 2003 at the meeting in Cancun. Oxfam preached the redeployment of agricultural subsidies towards social and environmental objectives and defended poor countries' rights to protect their agricultural markets." These ideas are also supported by other organizations, such as Brothers of Men,

7. Oxfam International, Who We Are, http://www.oxfam.org/en/about/who/index.htm (last visited Jan. 16, 2008).

8. Oxfam International, Mission Statement, http://www.oxfam.org/en/about/mission (last visited Jan. 16, 2008).

9. Oxfam International, Towards Global Equity: Strategic Plan 200I-2004, http:// www.oxfam.org/en/files/strat_plan.pdf.

10. Id.

11. Oxfam International, From Cancun to Miami: The FTAA Threat to Development in the Hemisphere (2003), http://www.oxfam.org/en/news/pressreleases2003/pr031113_ftaa_miami.htm. 
whose fight against "bad development" beginning in the 1980s provoked an increasingly profound partnership with autochthonous peoples.

In parallel, professional organizations like the Confederation Paysanne-the Farmers Confederation--preach the adoption of common strategies with southern countries. This point of view criticizes agricultural subsidies that support northern countries and that handicap the economies of southern countries. Rather than sticking to a humanitarian message, which, in fact, is not enough to remedy inequalities, Oxfam initiated a transnational reflection on the issue of poor countries' access to markets. These reflections were manifested in clearly argued studies, including ones studying the sugar and textile industries, as well as in campaigns carried out jointly on the European scale.

As we can see, this type of NGO not only intervenes on the ground by multiplying field initiatives of development and equitable trade, but also implements a total strategy based on a general vision of the economy that contests the excesses of neoliberalism. Oxfam does not oppose the liberalization of exchanges in itself but rather opposes the fact that this liberalization takes place without the consideration of the specific situations of the poorest countries. Oxfam further supports the maintenance of agricultural subsidies for certain types of productions in both Europe and in the United States, which caused real dumping in the agricultural sector.

Oxfam conducted an extremely effective campaign on the margins of the inter-ministerial conference in Cancun in 2003, in order to put trade at the service of sustainable development, and not the opposite. At the beginning, the negotiations were engaged and the agreement on poor countries' access to drugs was adopted, but the tension increased when four countries-Benin, Burkina Faso, Chad, and Mali-gave a report on the importance of cotton production and trade to their economies. They asked for the suppression of these subsidies, referencing the imbalance resulting from this sector's subsidies to producers from rich countries. This sectorial initiative on cotton crystallized the opposition of poor countries, led by India, Brazil, Kenya, and China, against the United States and Europe. In this part of the conflict, the NGOs, with Oxfam in the lead, took the side and the cause of developing countries.

Even before the beginning of the conference, Oxfam had started a petition called "The Big Noise" denouncing the injustice of international trade rules. The petition collected 3,000,000 signatures from around the world. It was grandly given to the director general of the WTO by Chris Martin, lead singer of the British group Coldplay, and Adrian Lovett, director of Oxfam campaigns and communication. The group, accompanied by a multitude of journalists, had just 
returned from a visit with Mexican corn producers during which they had witnessed the difficult living and working conditions of these farmers. Parallel media events - concerts and CDs of "The Big Noise"-and one week of action at the European Parliament, echoed by official statements and analyses diffused on the website of the organization, contributed to increase the pressure.

During the few days of the meeting in Cancun, the spokespeople of Oxfam were not satisfied with animating demonstrations; they also played the part of councilor for the poor countries and popularized their position with the media by holding several press conferences. The NGO had thus transformed the conference into a "morality play," as a member of the EU delegation described it, not without bitterness. ${ }^{12}$ A dialogue within the framework of a focus group, in which the NGOs were informed and consulted, had been established between the European commissioner in charge of foreign trade and the NGOs. The competence of an organization like Oxfam on agro-alimentary subjects is indeed recognized; it has its own experts, including high level economists, and the European Commission consulted them concerning delicate domains such as the sugar trade, where the pressure of lobbies is particularly strong. In Cancun, the EU delegation included NGO representatives who, because of their independence and convictions about fair trade, defended positions diametrically opposed to those of the rest of the delegation.

Reporting the events, some accused Oxfam of playing a "double game": on one side, that of seriousness and expertise, and on the other, that of systematic contestation, even if it meant spoiling the negotiation. In any case, the final failure of the conference clarified the impact that this type of organization has when it imposes the goals of its projects in the face of the diplomatic play of nation-states. NGOs do not enter directly into this play; for example, in Cancun, NGOs were not present in the room where the inter-ministerial conference took place. Their force existed in the way they transformed what was only an excursion of interstate relations into a true event and in their capacity to produce a spectacle of the immemorial confrontation between good and evil. The high number of Oxfam spokespeople among official negotiators is often mocked because certain countries do not even have the means to pay their representatives' traveling expenses.

In its own way, this globalized organization, with remarkable logistics, constitutes a power that it is now necessary to reckon with. If we try to analyze the nature of this power, we can see the combination of several elements: an economic base, professionalism, entrepreneurial initiative, media impact, and the prevalence of the themes of survival in Oxfam's actions and discourse. These features are not

12. Bruce Stokes, The Culture Clash at Cancun, NAT'L J., Sept. 20, 2003. 
specific to Oxfam; we find them in other large NGOs. In addition to contributions and gifts, the great humanitarian organizations receive the support of important national and international institutions.

Private funds represent the largest share of financial support to NGOs, surpassing international subsidies and national public financing. Organizations, such as the World Wildlife Fund (WWF), collaborated with companies to achieve goals from the licensing of products to a conservation partnership. Similarly, Max Havelaar, the pioneering NGO of fair trade, delivered its label to tea and coffee brands, affirming the respect of certain ethical principles. Its label concerns nearly a quarter of the twenty million workers of the coffee sector in the world; the NGO receives eighteen centimes per kilo of coffee beans that it labels "fair trade."

NGOs are continually looking for new modes of financing that enable them to develop their action. This situation constrains them to privilege the techniques of marketing in the humanitarian field. Like private companies, NGOs compete amongst themselves; this comperition encourages them to seek good positions (and why not, good victims) to provoke donors' favors. They devote more and more money to communication and fundraising and do not hesitate to implement an administration anxious to fulfill their financers' requirements of social profitability. In certain sectors the high growth of institutional financing has perverse effects because it leads to support of the zones where emergencies have the most media coverage, at the expense of other less media-friendly areas.

These criticisms reflect the fact that NGOs fall under a logic, which is not the same as that for public organizations, that brings them closer to the world of enterprise. At Oxfam, the managers I met came from the private realm where they had been executives. For example, the representative of the organization in Geneva began in a development bank in the United States; in Oxford one of the executives used to manage British Petroleum in Zambia. Former EU civil servants can also be found in NGO leadership positions. The fact that the personnel of NGOs comes from the elite of companies and large international organizations explains why the militancy of their origins made way for the realism of management methods.

This professionalization, in particular regarding the search for funds, imposes a style of communication that contaminates the NGO discourse and makes it conform to the mode of expression prevailing in the commercial world. It is quite obvious that, to go past the stage of denunciation and to avoid being locked in a mission of urgentist therapy, NGOs are confronted with the need to institutionalize themselves in their relation to public financing. They find themselves metamorphosed, which weighs on their autonomy and can modify their associative culture. Aren't 
we now dealing with a new pecking order, or rather with a new group whose function would be that of the beggars' interpreter among the powerful? It is also true that NGOs are the carriers of a new rationality that takes its place beside the logic of bureaucracy profits; we would thus see the emergence of a new logic of territorialization and mutualization which complicates the traditional relations between political power and economic power, between trade unions and companies.

An analysis devoted to the evolution of the contemporary international system signals the rise in power of private authority and the propensity of states to give this private authority an increasingly important place. ${ }^{13}$ The private international regimes prepare decisions and fix the agendas in the domain of the transnational regulation of environmental questions. "They contribute to the creation of global civil society, in which important transnational decisions are made in a private way. ${ }^{14}$ For Thomas Biersteker and Rodney Hall, NGO authority is based initially on their capacity to propose the list of topics to be negotiated. It is the result of a true lobbyism that requires a very intense presence in the international arena. Their authority also comes from their capacity of expertise. Lastly, it is necessary to insist on the moral character of NGO authority which is due to their positioning in social fields and their displayed progressivism.

One of the objective functions of NGOs is to operate the junction between the center and the peripheries and especially to reinforce the pressure of the peripheries on the center. From the point of view of NGOs, it is important to influence international powers by putting the problems created by globalization in the foreground, whether social and human abuses, ecological disorders, or the deepening of the gap between the North and the South. One result in which NGOs can take pride is the imposition of a responsibility principle on the international scene by making it the moral obligation of states to either act or repair. Their many campaigns made governmental actors aware that the survival of humanity passes through the interdependence of the units that make it up and that there is a strong solidarity between generations.

Should we be surprised that the qualitative change that NGOs experienced caused an ensemble of interrogations that reflect the critical stances mentioned in this article? The tensions that surfaced initially concerned the modes of managing civil society. Is it necessary to make the functioning of NGOs evolve in the direction of rationalization, in conformity with the model of the most powerful

13. Thomas Biersteker \& Rodney Hall, L'émergence des Autorités Privées, Alternatives Économiques, Jan. 1, 2001 at 17.

14. Id. 
private companies? Or must they incarnate above all the ideal of activism and solidarity in the lineage of the associative movement where they have their roots? We can just as well wonder whether the specificity of NGOs is not due precisely to a double anchoring: political in terms of actors in the global polis and economic in terms of companies centered on survival. From the political point of view, NGOs can pride themselves in bringing "the voice of those without voices" to the public sphere, in making suffering heard, and in bringing to light this "misery of the world" present in the most removed corners of the planet. These organizations would be the vectors of policy insofar as-through their action and through the spectacle they produce of the misery of the world faced with multiple forms of exploitation and inequalities-they show what is hidden in the process of neoliberal globalization and make a discordant discourse heard in the face of well articulated statements of the dominant forces.

When the actions of NGOs are considered, it is undeniable that they contribute to the creation of breaking points that allow the introduction of a political space where the voice of those without voices can be heard. In this way, even if we can legitimately challenge their claims to incarnate "civil society," what is certain is that they induce disorder and discordance in the interstate concert. Is this to say that these organizations are in themselves subversive and of a different nature than other international institutions? By observing the professionalism of NGOs and their executives' membership in the club of globalized elites, we quickly understand that these leaders have nothing in common with the ideal of the professional revolutionist who directed the cosmopolitan militancy of the past. In reality, engagements of the ethical type generally motivate managers in charge of the big NGOs to work in non-profit instead of in the private sector or in the great international institutions. This ethical engagement does not imply calling the capitalist system into question and introducing a new social order.

As I observed among Californian entrepreneurs, the invocation of ethical values does not concern spiritual enrichment but proves to be completely coherent with an economic project centered on personal freedom articulated harmoniously with the collectivity. He who wrote "[we believe] that all individuals have the innate potential to make life better for themselves and their communities, ${ }^{15}$ is not a great reformer, but one of the most skilled businessmen of his generation: Pierre Omidyar, the creator of eBay. The fact that there are large firms that now claim to

15. http://www.donorschoose.org/about/our_supporters.html;jsessionid=186FAF4FE9351CF B052148B522CB0122 ?zone $=201$ (last visited May 8, 2008). 
practice "virtuous capitalism"16 and intend to make ethical standards prevail does nothing but reinforce a more general movement in which "multinationals of civic virtue" take part. ${ }^{17}$ The political effects of NGOs are mainly due to their multisite position-both in the high ranks of the international as well as peripheral areas-and to the back-and-forth that they establish between the voices of the periphery and the secret meetings of the center.

We should, however, never forget that large humanitarian and development organizations, who are private actors, maintain, with their status and their operating mode, a strong complicity with the business universe. Like businesses, NGOs arose foremost from the economic sphere. As soon as we point toward their political dimension, which is based on the effects they produce in the public realm, it is important to add that their impact is related to the primordially economic character of their action. We place ourselves in the field of the economy of survival that constitutes the specific field of intervention of these organizations. One spontaneously associates the exchange of goods and the prevalence of the market to the economy. Increasingly, intense circulation of goods is how the reality of globalized exchange presents itself. In this context, the economy of survival seems to contradict the principles governing the market economy. Where the latter exalts the freedom of exchange, the former underlines the need for human intervention. Moreover, the objects of the economy of survival - above all, bare life, the excluded, the needy, and the humanitarian emergency-concern actions antithetic to economic principles. ${ }^{18}$

The gift without counterpart-and not exchange-is the principle of humanitarian action. Marcel Mauss wrote that the gift is "one of the human foundations on which our societies are built." ${ }^{19}$ Admittedly, the practices he analyzes are those of traditional societies in Melanesia, Polynesia, Alaska, and Northwestern America. The kula of the Trobrianders or the potlatch of the Tlingit and the Haïda are quite far from contemporary philanthropic initiatives. Mauss, however, did not hesitate to generalize his insight, even extrapolating "moral conclusions" in which he evokes the "uses" of his time, the role of social security systems, and

16. Marie Cuillerai, Le Capitalisme Vertueux (2002).

17. See Yves Dezelay \& Brian Garth, Dealing in Virtue: International Commercial Arbitration and the Construction of a Transnational Order (1996).

18. Marie Cuillerai, Le réel par effraction: qu'est-ce qu'une intervention économique?, Conference, Autour de "l'intervention:" protagonistes, logiques, effets, Université de Montréal (Oct. 23-25, 2003).

19. Marcel Mauss, The Gift: The Form and Reason for Exchange In Archaic Societies 4 (W.D. Halls trans., W.W. Norton \& Co. 2000) (1950). 
mutual benefit societies instituted within the framework of trade unions and professional associations, as well as certain states' coverage of social security. Being prescriptive, he recommends an effort of wealthy classes to contribute to the collective wellbeing: "As is happening in English-speaking countries and so many other contemporary societies, whether made up of savages or the highly civilized, the rich must come back to considering themselves-freely and also by obligation-as the financial guardians of their fellow citizens. ${ }^{20}$

By stressing the responsibility of rich people, the author of the The Gift illustrates the need for developing practices based on solidarity in counterpoint to the market economy. However, is it possible to speak about complementarities between the market economy and the economy of survival? Can the economy of survival seem like a possible alternative to the market and the increasing dehumanization of commercial relations? If Mauss also largely inspires the most radical partisans of an alter-economy or an economy based on solidarity, it is less because they refer to the paradigm of the gift and reciprocity and more that they see in the exemption from payment, especially in the claim of universal citizenship, the horizon of a promising utopia. By leaning on the experience of intermediate institutions that structure the experiments of an economy based on solidarity, advocates of an alter-economy seek to promote forms of action that combine institutional initiatives inside the economic world, like the funds of ethical investments, the labels "fair trade," or the projects of citizen enterprise. Thus, drawing on Mauss and Polanyi, the solidarity economy uses models other than those of self-regulation. ${ }^{21}$ It wants to institute a true hybridization between the monetary bond and the social bond. The ambition of a "plural economy" appears on the horizon, where the economy of public goods, the economy of reciprocity, interdependent, and associative, and the cash economy would coexist intertwined with one another.

What gives the NGO phenomenon its rather unusual character is that the activity of these organizations is focused on the economy of survival. Consequently, their urgency-imbued stance also fits with an outlook of a future made uncertain by threats of merchandization of the universe. The economy of survival carries within it the issue of sustainability. We see this clearly in the area of the environment, where catastrophes regularly give us cause to evoke the responsibility of a productivist development model centered on profit. The reactions of the populations of developed countries to the recent great natural disasters are en-

20. Id. at $68-69$.

21. See generally Mauss, supra note 19; Primitive, Archaic and Modern Economies: Essays of Karl Polanyi (George Dalton ed., 1968). 
tirely symptomatic of the response elicited by crisis situations. We saw this at the time of the tsunami, the tidal wave that, in December 2003, ravaged the coasts of a dozen southern Asian countries, leaving hundreds of thousands dead. We witnessed at this time an immense outpouring of collective generosity. The intensity of the solidarity can be explained by the timing (the announcement of the catastrophe in the middle of the holiday period and the feeling of living in peace and prosperity at a moment when others were abruptly stricken) and by the fact that westerners had been more directly affected than had been the case during other catastrophes (holidaymakers on the Asiatic coast had not been spared).

Other than the influx of public finances, very large gifts came from the private sector. To cite the big pharmaceutical companies, Pfizer gave $\$ 10$ million to charitable organizations operating in the region as well as $\$ 25$ million of medicine; Abbott Laboratories distributed $\$ 4$ million, half in cash and half in medicine and food; Bristol-Myers Squibb gave $\$ 1$ million; Johnson and Johnson gave $\$ 2$ million. The number one finance company in the world, Citigroup, distributed $\$ 3$ million, between the Red Cross, local NGOs, and on-site reconstruction. WalMart donated $\$ 2$ million that it collected in its stores. ${ }^{22}$

Following the tsunami, the mobilized NGOs appealed to private individuals. The sheer scale of private donations, particularly in Europe and the United States, shows the impact of the economy of survival on individual behavior. Even in France, a country not usually noted for great charitable enthusiasm, ${ }^{23}$ individual rallying to the cause took an impressive turn in the shape of a veritable humanitarian telethon. In one day, Short Message Service (SMS) donations reached over 1 million. Looking back, what is striking about the breakdown of the donations is the fact that the amount of private donations almost reached that of the effort agreed to by the state. This was an unprecedented phenomenon, suggesting that the citizens wanted to express their commitment to the humanitarian effort directly. In this context, the use of technologies like the Internet or SMS - which make it possible to be directly involved in a global-level action while being confined to a local site-contributes to changing the traditional order of things. The individual can now step to the fore as a global player.

In the face of the traditional mediations embodied by national governments, a global donor action group is forming. This is embodied in the media in two ways. On one side, we are shown people admirably involving themselves in order

22. U.S. Department of State, Going the Distance: The U.S. Tsunami Relief Effort (2005)

23. According to the Observatoire de la Générosité de du Mécénat, only $46 \%$ of the French population are regular donors, compared to $75 \%$ of Americans. 
to come to the aid of victims, either on the ground or by inciting mobilization in their community or company. These people, "like you and me," acquire the status of the representative of the charitable collective. On the other side, a different type of representation of the charitable élan is illustrated by emblematic figures of the humanitarian such as Mother Theresa, or Abbé Pierre and Bernard Kouchner in France, figures to whom politicians show deference and humility.

The remarkable aspect is the manner in which the political authority increasingly steps aside when confronted with types of action and discourse that deal with issues of global impact and have a relationship to our survival. Politicians take advantage of the cachet of these emblematic figures, or, when failing do so, are content to manage the day to day crisis situations with which they are confronted. If, by politics, we mean the relationship that unites the individual with the group and the way in which the individual sees his integration into the city, we may well wonder if, on this level, there is not some profound change going on. In fact, our behaviors and the priorities that determine group action, in addition to the very fact that rallying of this nature and extent is possible when confronted with this type of catastrophe, reflects both anxiety and new awareness. The new awareness is that the world we live in may disappear and that, eventually, the survival of the species is threatened. This reaction is absolutely consistent with the response elicited by the theme of sustainability. Without doubt, it expresses an even more profound "anthropological anxiety." The NGO phenomenon fits into this perception of a world marked by this threat and risk, where tragic events regularly remind humans of the precarious nature of their situation.

In the case of the tsunami, the emotion triggered by the catastrophe had the paradoxical effect that one of the biggest NGOs, Doctors Without Borders, asked donors to stop giving, in the name of honesty and transparency. The NGO had already received $€ 40$ million. When other organizations criticized this decision that could discourage future giving and Action against Hunger accused Doctors Without Borders of having "rich peoples' problems, whereas we deal with poor peoples' problems," Doctors Without Borders invoked the demand of "traceability of payments received." ${ }^{24}$ In other words, the role of an NGO is not to accumulate amounts of money that it will then distribute when it feels like it among different humanitarian projects. It matters that donors know that their money is used for the cause that mobilizes them. The ethical concern that conditions this attitude is inseparable from a more general conception of management of the economy of survival. Here, we find the idea that the humanitarian association is

24. Gerard Bon, Paris Urges More Tsunami Aid After Group Says Stop, Reuters, Jan. 4, 2005. 
accountable and that the amount of gifts alone does not guarantee their effectiveness. In parallel, the issue of "return on investment" is raised. Ethics and rationality come together to determine the application of the economy of solidarity.

Although these practices have different ends from those of the market economy, it is clear that forms of complementarity can exist between the economy of survival and globalized capitalism. Not only can the former function as a pressure valve for the latter, but, as we can see, the economy of survival is inspired by the modes of management that globalized capitalism developed. We could thus argue that-far from incarnating an alternative project- humanitarian workers, the champions of fair trade, simply comfort the global system. There is a clear gap between the radical positions that confront this system head-on and the system and discourse of big NGOs, like Oxfam and the WWF, engaged in the fight against inequalities without questioning the market economy.

Projects of an ethical vocation, which aim at rebalancing commercial relations between producers and workers of the South and consumers of the North, hope to make certain fundamental principles prevail. These fundamental principles, including the definition of a fair price allowing the producer and his family to live with dignity, and working conditions corresponding at least to the standards of the International Labor Office, are criteria considered to mark progress. They contest the reductive character of concepts that exalt the homo economicus and that make money and market into an end rather than a means. For them it is necessary to give the individual subject of the economy the sense of the values and relations which, in their complexity, give sense to life and express the dignity of the human condition. This exaltation of the individual is obvious in the conceptions that the ideologists of fair trade develop, beginning with Muhammad Yunus, the founder of Grameen Bank in Bangladesh, when he insists on the irreplaceable role of independent work. ${ }^{25}$

Certainly, today, organizations whose purpose is the economy of survival represent a powerful opposition force. NGOs and the social movements have never fought as hard as they do now. They brought about the failure of the Multilateral Agreement on Investment (MAI), which was proposed by the Organisation for Economic Co-operation and Development (OECD) and highly favorable to entrepreneurism. They caused powerful genetic engineering companies in Europe to back off. We saw them play a leading role in the failure of the WTO negotiations in Cancun, where cotton producers of developing countries rejected an

25. Muhammad Yunus \& Alan Jolis, Banker to the Poor: The Story of the Grameen Bank (2003). 
agreement the United States wanted to impose on them. Gradually, political and economic powers have understood that they now really have to 'reckon with' what is referred to under the controversial label of 'civil society.' On the NGO side, the question now on the table is whether to follow a strategy of automatic protest by favoring the tribunal function or to contribute to global governance by gaining acceptance for their views, which would involve the use of both pressure and negotiation. An organization like Oxfam, which played a leading role in the failure of the Cancun conference, still claims to support the existence of the WTO, inasmuch as it means the implementation of regulation at a global level.

The aim of these NGOs is not to reject the market economy, but rather to establish a "connection" between the problems of people in the field and the global governance viewpoint and bring out the effects of this within that market economy. This is how to get concrete results and to give the southern countries a chance to improve their economic situation through access to worldwide trade. What is new in terms of the charitable purpose of the NGOs is not only their ability to connect the humanitarian problem to that of development, but also the way in which they have been able to link the issue of development to that of global governance on the basis of interpellations coming from poverty and concerning the distribution of wealth. It is not a matter of accepting the rules of the game as laid down by the WTO as an intangible fact, but of publicizing, in this framework, the main question, which can be summed up in the following way: Why does the regulation of international trade tend to favor preferential systems that benefit rich countries?

\section{Conclusion}

This article explored the role of NGOs in what I call "global politics." The complexity of global politics means that it is not just a substitute for existing politics. So far, those who have tried to think through and promote the overtaking of the nation-state, using concepts or constitutional formulas, have gotten nowhere. Today, alongside the political places of sovereignty organized around the institutional division of executive and legislative, another space is emerging where the legitimacy of a decisionary monopoly becomes increasingly blurred. Global politics casts us into a regime of anticipation and bears the hallmarks of the lack of fulfillment. It can neither be contained in terms of power balances nor thought of as a superstate form. It is developing, to some extent, alongside the world of territorial sharing without imposing itself on states and on traditional regimes of sovereignty as an overshadowing power. Between the nation-state and global politics 
we find the same polarity as that which exists between the system of harmonious living together (convivance) and the system of survival. Today, global politics is, to a high degree, dependent on the strategies of nation-states. However, as the impact of initiatives dealing with the economy of survival show, global politics imposes its own system and puts under pressure those powers that control it only imperfectly. Perhaps it is time to modify our vision of politics, obscured as it is by the search for a predominant and omnipotent political "site," in light of the fact that what is actually evolving is a set of systems that undermine the perception of sovereignty that has long been the foundation of western governmental practices. With global politics, the issue now on the agenda is that of a politics of survival, which is being expressed in most varied ways in the public sector. 